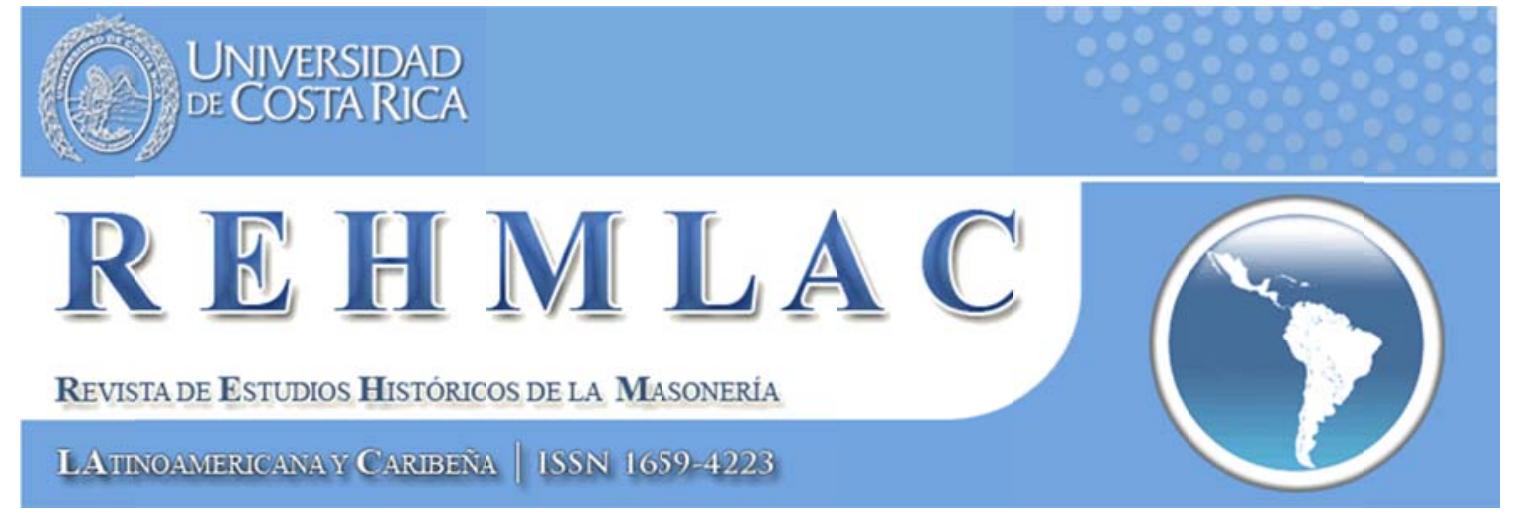

\title{
"The Complicated Origins of Cuban Masonry: The Temple of the Theological Virtues"
}

\author{
Eduardo Torres Cuevas
}

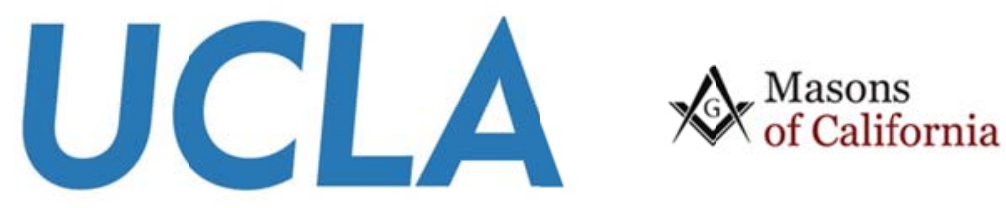


Eduardo Torres Cuevas. Cuban. PhD, is a philosophy professor at the University of Havana. He is director of the José Martí National Library of Cuba and the Cuban Academy of History, and has published several books about the history of Cuban Freemasonry. E-mail: torres-cuevas@,cubarte.cult.cu

Date received: December 22, 2012 - Day accepted: February 27, 2013

\title{
Keywords
}

History, Freemasonry, Origins, Cuba, Temple of the Theological Virtues

\section{Palabras claves}

Historia, masonería, Orígenes, Cuba, Templo de las Virtudes Teologales

\begin{abstract}
How was Freemasonry introduced in the Spanish Empire's Cuba? In those waters, constantly agitated by the struggle between the various imperialist forces during the transition between the eighteenth and nineteenth centuries, several different Freemasons and Freemasonries constantly traveled. This article offers an answer to this question, showing the dynamics of the complex origins of Freemasonry in Cuba.
\end{abstract}

\section{Resumen}

¿Cómo se introduce el fenómeno masónico en la Cuba del Imperio español en cuyas aguas, permanentemente agitadas por la lucha entre las diferentes fuerzas imperialistas del entre siglos (XVIII-XIX), iban y venían distintos masones de distintas masonerías? He aquí con este trabajo una respuesta que presenta la dinámica general de los complejos orígenes de la masonería en Cuba.

(C) Eduardo Torres Cuevas and REHMLAC.

Academic Committee: Miguel Guzmán-Stein (Universidad de Costa Rica, Costa Rica), José Antonio Ferrer Benimeli (Universidad de Zaragoza, España), Margaret Jacob (University of California Los Angeles, United States), Eduardo Torres Cuevas (Universidad de La Habana, Cuba), María Eugenia Vázquez Semadeni (University of California Los Angeles, United States), Éric Saunier (Université du Havre, France), Andreas Önnerfors (Lunds universitet, Sverige), Samuel Sánchez Gálvez (Universidad Carlos Rafael Rodríguez de Cienfuegos, Cuba), Roberto Valdés Valle (Universidad Centroamericana “José Simeón Cañas”, El Salvador),

Céline Sala (Université de Perpignan, France), Dominique Soucy (Université de Franche-Comté, France),

Guillermo de los Reyes Heredia (University of Houston, United States), Felipe Santiago del Solar Guajardo

(Universidad ARCIS, Santiago de Chile), Carlos Francisco Martínez Moreno (Universidad Nacional Autónoma de México, México), Michel Goulart da Silva (Universidade do Estado de Santa Catarina, Brasil)

Invited Editor: María Eugenia Vázquez Semadeni (University of California Los Angeles, United States)

Editor: Yván Pozuelo Andrés (IES Universidad Laboral de Gijón, España)

Director: Ricardo Martínez Esquivel (Universidad de Costa Rica, Costa Rica)

Web: rehmlac.com/

E-mail: info@rehmlac.com

P.O.B.: 243-2300 San José, Costa Rica 
Cited in:

Academia.edu

Aladin. WRLC. Libraries Catalog

AFEHC. Asociación para el Fomento de los Estudios Históricos en Centroamérica Biblioteca de Georgetown

CRICCAL, Université Sorbonne Nouvelle Paris 3

CERGE EI. Portál elektronických časopisů. Univerzita Karlova v Praze

Departamento de Filosofía de la Universidad Centroamericana “José Simeón Cañas"

Dialnet, Universidad de la Rioja

Directorio y recolector de recursos digitales del Ministerio de Cultura de España

DOAJ. Directory of Open Access Journals

Freemasonry and Civil Society Program at UCLA

Fudan University Library Academic Resource Portal

Google académico

Institute for the Study of the Americas at University of London

$$
\text { Latindex (UNAM) }
$$

Latindex.ucr. Repositorio de revistas de la Universidad de Costa Rica

Library Catalogue of University of South Australia

Museo Virtual de la Historia de la Masonería de La UNED

Nuevo Mundo. Mundos Nuevos

REDIAL. Red Europea de Información y Documentación sobre América Latina

SID. Sistema Integrado de Documentación. Universidad Nacional de Cuyo

Toronto Public Library

UBO. Revues en ligne. Service Commun de Documentation, Université de Bretagne Occidentale

Universia. Biblioteca de Recursos

University of Wiscosin-Madison Libraries

Western Theological Seminary. Beardslee Library Journals

cc) creative

coininons
License type

"Attribution-Noncommercial-Share Alike" 


\title{
“The Complicated Origins of Cuban Masonry: The Temple of the Theological Virtues"
}

\author{
Eduardo Torres Cuevas
}

\section{Introduction}

In 1875 Francisco de Paula Rodríguez, one of the most important figures of the Grand Lodge of the Island of Cuba, wrote:

And for that insolent mistake that attributed to us a political role $[\ldots]$ continued traps and persecutions were carried out against the Institution. On this point we have learned a lot. Instead of Liberty, Equality and Fraternity, which is an eminently political slogan, has been reinstated the one that England and the United States have, Fraternal Love, Charity and Truth ${ }^{2}$.

Rodríguez' text was part of an important readjustment that took place within Cuban Masonry, and which differentiated it from the Anglo-Saxon concept of Masonry. Until then, the influence of French Masonry was more than evident. In contrast to the Grand Lodge of Columbus, the most important Masonic body of the previous decade had been the Grand Orient of Cuba and the Antilles which, like its French counterpart, had adopted the revolutionary triptych of "Liberty, Equality, and Fraternity" and had presented some liturgies and a program with clear political profiles, hoisting republicanism, deism, laicism, and the individual and collective liberties. It was not until the 1920s that Cuban Masonry accepted the points proposed by the United Grand Lodge of England as ancient limits and dogmas to define the regular character and the recognition of a Masonic body. (The facts of the United Grand Lodge of England were compiled in the Código Masónico published in accordance with Decree No. 20, April 16, 1931). For historic reasons, and because of the content of the documents related to the origins and development of Cuban Masonry during the nineteenth century, it is necessary to specify the varied origins and complexity of the Masonic bodies that emerged in Cuba in the nineteenth century.

\section{The Caribbean as epicenter of American Masonry}

The origins of Cuban Masonry are not limited to the internal evolution of the country; they have a close bond with inter-imperial conflicts in the wider cultural zone called El Caribe $^{3}$. In diverse and numerous ways, the ideas of the Enlightenment (English, French, and

\footnotetext{
${ }^{1}$ I want to thank Fernando Serrano y María Ornelas for translating this paper and Laura Normand for revising it.

${ }^{2}$ Revista La Gran Logia 6 (La Habana, 1904).

${ }^{3}$ There exist, at least, two different meanings of the concept of El Caribe. One is geographical and refers to the islands and continental territory that circumscribe the Caribbean Sea. The other is cultural-historical and would cover the wide territories of the Northamerican south (especially Louisiana and Florida), part of the Gulf of Mexico and the islands and continental territories that surround the Caribbean Sea. This second
} 
Spanish) entered this area, as well as of the revolutions at the end of the eighteenth century and the start of the nineteenth century. Sailors, adventurers, writers, and numerous immigrants not only brought news and documents, but also participated in the many confrontations that occurred during this period. Between 1791 and 1794 the first stage of the slave insurrection of the French colony of Saint-Domingue occurred. In 1804 a slave by the name of Jean Jacques Dessalines defeated the French military and proclaimed an independent Haiti the next year.

It was from Haiti that the first Masonic lodges - and the Masonic ideas and concepts they contained-arrived in Cuba. Nonetheless, it is important to clarify some aspects surrounding that process. First of all, in those times there existed more than twenty important Masonic bodies and, in fact, they were rivals with each other. One of the most notable conflicts was between the Grand Lodge of England and the Grand Orient of France. English Masonry had declared its loyalty to the king and the British Empire; the Grand Orient of France had expressed its tendencies to republicanism and to liberal ideas, represented in the slogan "Liberty, Equality, Fraternity." Napoleon Bonaparte, understanding the usefulness of French Masonry, placed the Grand Orient under the direction of his closest collaborators and marshals. One of the most important figures in the empire, Cambacérés, was designated by the emperor to reorganize and direct French Masonry ${ }^{4}$. The struggle between the English and the French also had its expression in the struggle between the English monarchical Masonry and the French bonapartist.

In some French Masonic tendencies, the Phrygian cap was used as a symbol of liberty and a rejection of the old regime (borrowed later by several American independence movements). Much of what was used as a metaphor in France, such as the idea of "breaking the chains of slavery," was a real referent for the slaves in Haiti. What was merely a political notion in France was a concrete reality in Haiti. For its part, French Masonry was strongly divided. One of the Masonic rites that emerged in the middle of the eighteenth century was that of "Perfection," which embraced more radical principles than those observed by the Grand Orient of France. This rite was adopted by several lodges in the city of Bordeaux, which initiated people from Saint-Domingue. It is notable that the Masonry established in Saint-Domingue was the Rite of Perfection and not the one from the Grand Orient of France. On August 27, 1761, the Rite of Perfection issued the patent of the deputy inspector of SaintDomingue to Étienne Morin, "with the purpose to extend in America the masonry of Perfection", Morin not only spread the Masonry of Perfection; he developed new degrees and introduced important innovations that led to the emergence of a new Masonic rite.

No less outstanding was the process that began in the Caribbean geographic area under the influence of Perfection Masonry. Here, one line of cooperation and creation of lodges extended from Haiti to Louisiana, passing by Cuba. In the process, Perfection Masonry was enriched and modified. In 1797 in Louisiana, still under French control, this Masonry created

conceptualization is extremely important because, independently of the actual national locations, through them occurred historical circumstances that interrelated them in all aspects.

${ }^{4}$ François Collaveri, Napoleón franc-maçon? (Paris : Taillandier Bibliothèque Napoléonienne, 2003).

${ }^{5}$ Eric Saunier, Encyclopédie de la franc-maçonnerie (France : La Pochothèque, 2000). 
eight new degrees and led to Ancient and Accepted Scottish Rite Masonry: together with the York Rite, it became one of the most widespread Masonic rites in America.

Between 1763 and 1790, there are numerous documents that speak of the presence of Masons in Cuba, coming from England as well as from the French colonies. But the most significant fact is that at the outset of the Haiti revolution, relations between Masons from both islands increased. In 1798 in Cuba, the first officially recognized Masonic lodges appeared. Four of these emigrated from Haiti to Cuba, keeping their French names. Two of them were established in Santiago, Cuba: La Persévérance and La Concorde. The other two were established in Habana: L'Amitié and La Bénéfique Concorde. Besides the fact that these last two gave their name to the Havana streets of Amistad and Concordia, the most important fact is that the L'Amitie lodge had an active role in the first phase of the Haiti revolution.

Little information exists about the other three lodges except that they were in fact active transmitters of the explicit ideas found in the first Haitian constitution promoted by Toussaint Louverture. See what a Havana newspaper of the period published about the inscriptions that appeared on the walls of one of these lodges (without specifying which one):

At the turn of the street a white man with a black [man] dressed with a torn shirt and long pants prostrated at the feet of that whom he embraces by the knees. He has a book in the hand and in it: the true patriotism is the profound hatred of injustice and all forms of arbitrariness and tyranny. At his feet: The American patriot lover of mankind, the motherland and liberty. There is another figure pointing to a book and from there: the sacred freedom of the press authorizes us to speak and write for our cause ${ }^{6}$.

As is evident, the wall of this lodge is a clear reference to the paternalistic abolitionism of the white man, which made sense in the times of Toussaint Louverture but not in those of Dessalines.

On December 17, 1804 a transcendental event occurred in the history of Cuban Masonry. That day a charter was given to the first lodge created for Cuba. Significantly, its name is in French: Le Temple des Vertus Théologales. The charter, in possession of the Grand Lodge of Cuba A.L. and A.M., shows that the majority of its members were French originating from Haiti, and that it had already been meeting for two years prior. It is necessary to clarify here two fundamental aspects in relation to this lodge: first, its official emergence in Cuba is the same year that the Napoleonic troops invade Haiti; second, by that time, Napoleon had already subordinated the Grand Orient of France to his imperial interests. This explains why the French Masons coming from Haiti would look for the charter for the new lodge in a North American Masonic body, the Grand Lodge of Pennsylvania - at that time, political center of the United States - so that it was neither subject to the French Grand Orient nor the Great British Lodge. The lodge characteristics seem more in the style of the Girondists, in the Lafayette style, as opposed to Napoleon and republican by conviction. The North American Masonry as well as that of Louisiana was of republican influence, which was also expressed in the contents of the Ancient and Accepted Scottish Rite. This last one was taking form in America. One skill of the bonapartists was to accept this rite in the Grand Orient of France.

\footnotetext{
${ }^{6}$ Diario de la Habana (March 24 $\left.{ }^{\text {th }}, 1812\right)$, t. IV, no. 594, 1.
} 
The first lodge created in Cuba was soon transformed to the first Cuban lodge; it changed its name to Spanish, El Templo de las Virtudes Teologales (The Temple of the Theological Virtues). By that time the majority of its members were Creoles. In the annals of the history of Cuba this lodge occupies a distinguished place in the initial processes related with independent thought and action. Its first master was the French Joseph Cerneau. Until today, I have not been able to find documentation that clarifies the true significance of this figure in the histories of Haiti, Cuba, the United States, and France. The truth is that North American Masonic historians catalogue him as "the mason that most damage did to U.S. masonry,"7 on their part, the Cuban Masons call him "enthusiastic and combative brother"8; and the governor of Cuba, Salvador del Muro y Zalazar, Marqués de Someruelos, attributes to him "a revolutionary character" " for which he expelled him from Cuba. The nexus between Cerneau and Morin is still to be established, but there is no doubt that the first was a promoter of the Scottish Rite at its birth.

It is in this lodge's bosom, in 1809, that one of the first Cuban separatist conspiracies emerges, known in our history as that of Román de la Luz, who is considered responsible. The main individuals were all distinguished members of the Temple of the Theological Virtues, among them the same Román de la Luz, rich landowner from Havana; the warden of the lodge, Manuel Ramírez; and the captain of the Regiment of Whites of Havana, Luis Francisco Bassave. Not only were these prominent Masons figures in the conspiracy, they were also free black men and mulattos. The causes for which they conspired - that is, the objectives of the movement - are still not clear, and remain part of contemporary debates.

Of all the members of the lodge involved in the conspiracy, the one of major historic relevance is José Joaquín Infante. A lawyer from Bayamo and part of the Spanish judiciary body in Cuba, Infante was able to escape the arrests carried out by the colonial authorities. Soon after, he found himself in Venezuela, forming part of the Bolivarian independence movement. What gave him a special transcendence in Cuban history was his writing and publishing of La primera constitución para una república independiente (The First Constitution for an Independent Republic). It is likely that he first drafted the document around 1810 - drafting two versions, in fact, but actually first publishing it in 1811 in Caracas, a year prior to Spain approving its first constitution, that of Cádiz. A close reading of this document is noteworthy for two reasons: first, the clear influence of the first Haitian constitution, elaborated by Toussaint Louverture; and second, the presence of the Masonic ideas found in The Ancient and Accepted Scottish Rite, a fact that sets it apart from the Spanish Constitution of Cádiz of 1812. The boldest move for its time is seen in the declaration of the "lay state," that is to say, in the separation of church and state: the division of powers of the state and the establishment of freedom of religion, concurrent with the granting of other liberties and a notion of sovereignty residing in the people. The Infante

\footnotetext{
${ }^{7}$ Aurelio Miranda y Álvarez, Historia documentada de la masonería en Cuba (La Habana, 1933), 30. On Cerneau figure can also be consulted Encyclopédie de la franc-maçonnerie, 133-134.

${ }^{8}$ Francisco Ponte Domínguez, La masonería en la independencia (La Habana: Editorial Modas Magazins, 1954), 14.

${ }^{9}$ Miranda y Álvarez, Historia documentada, 30.
} 
Constitution marked a path that would be repeated in all subsequent Cuban constitutions; it also marked the options between a lay and independent republicanism, and a reformism within the framework of the Spanish monarchy ${ }^{10}$.

In turn, the figure of Captain Bassave, from a different perspective, offers a significant appeal, for Captain General Someruelo accused that he "convoked and excited blacks and mulattos to the dregs so that he may stir them up, and commanding that rabble he would have, without a doubt, cooperated with the plan of Don Román de la Luz ${ }^{11}$ ". The documents relating to this conspiracy indicate that Bassave enjoyed popularity in the most humble neighborhoods of the capital and that he attempted to lead the battalion of Milicias Disciplinadas de Pardos y Morenos in revolt, as well as a certain group of black and mulatto workers from poor Havana neighborhoods. The ties remained secret. On Monday, March 16, 1812, organized by José Antonio Aponte - a free black carpenter who, according to popular legend, was also among the black troops of Havana that participated in the U.S. Revolutionary War - these groups mobilized to take the principal forts and quarters of the city. Aponte, who had ties with the Masons of the Temple of the Theological Virtues lodge, was seized on April 7, condemned to death without a trial, and hanged on April 9. His head was displayed in an iron cage at the entrance of Havana along the Jesús del Monte road.

The Masonic lodges that were active at the time in Cuba were disbanded around 1814. Nevertheless, the Temple of the Theological Virtues secretly persisted during the period of restoration of the old regime under the rule of Fernando VII. The monarch had expressly prohibited this type of organization within the Hispanic empire by royal decree on January 19, 1814, issued by the Consejo de Regencia, condemning the crime of Freemasonry. In 1820, after years of secret activity, the Temple of the Theological Virtues resurfaced as part of the rights granted during the constitutional triennium (1820-1823).

From a methodological point of view, we have observed in other works the importance of distinguishing between the different types of Freemasonry extant in the nineteenth century in America: on the one hand, the rise of secret societies with political objectives that adopt the organizational form of Masonry, like in the cases of the comuneros, carbonarios, and anilleros in Cuba, fundamentally constituted by political groups of Spanish residents on the island; and, on the other, secret societies with independent persuasions, the likes of the Cadena Triangular, Soles y Rayos de Bolivar, and Caballeros Racionales. The same holds for the society discovered in 1826 by the name of the Gran Legión del Águila Negra, which was also associated with the Mexican president Guadalupe Victoria ${ }^{12}$.

In the Cuban case, it is in 1820 that, for the first time, the first two Masonic organizations are officially established. The first, the Gran Logia Española de Antiguos $y$ Aceptados Masones de York, was established on November 30, 1820; the second, the Gran Oriente Territorial Español Americano del Rito Escocés began its workings on May 14, 1821.

\footnotetext{
${ }^{10}$ Joaquín Infante, Homenaje a este ilustre bayamés autor del primer proyecto de constitución para la isla de Cuba (La Habana: Imprenta El Siglo XX, 1930).

${ }^{11}$ José Luciano Franco, La Conspiración de Aponte (La Habana, 1963), 21.

12 Eduardo Torres Cuevas, Historia de la masonería cubana. Seis ensayos (La Habana: Editorial Imagen Contemporánea, 2004).
} 
Although in the General Rules of the York Grand Lodge it was stipulated that "the good Mason ought not to mix himself in conspiracies against the state; he ought to be loyal and obedient to the state of his residence; he ought to be a peaceful and tranquil citizen," in the same chapter and article it also stated that: "the love of one's country will be the first objective that occupies his heart. All sacrifice is nothing but the amount it is worthy and deserving of ${ }^{13}$ ".

These Masonic entities, different from secret societies in their substance, also had at that time a clear political content. In respect to the York Rite of Freemasonry, there existed a strong American influence. Among its orders was "extending the area of liberty." The North American Joel Robert Poinsett, a secret agent and confidant of the government of the United States, had an active participation in the promotion of the York Rite in diverse parts of Latin America. He was present in Cuba at the time that this Masonic rite developed on the island. Among the writings of Poinsett one finds a letter dated October 14, 1825, confirming the political makeup of the York Rite and attributing to it a fundamental role in the creation of this type of Masonry in Mexico: "With the intent of countering the actions of the fanatic party in [Mexico City] and, if possible, diffuse to a broader degree liberal principles amongst those who govern the country, I incited and aided a certain number of respectable persons(...) in forming a York Grand Lodge of Freemasons ${ }^{14}$."

On the contrary, Scottish Freemasonry was in the hands of prominent figures of Creole heritage on the island. The grand master was the powerful Count of O Reilly, one of the wealthiest Cuban landowners. Among the most notable Scottish leaders was Nicolás de Escovedo, one of the most prominent disciples of Félix Varela, the independent priest who was the first to give rise to a Cuban philosophical thought.

This is not the place to discuss the patriotic and conspiratorial activity of secret societies like Soles y Rayos de Bolivar, but one ought to note that the principle founding figures of that secret society were distinguished Latin American independents, at that time residents of Havana: the Argentinean José Antonio Miralla; the Ecuadorian Vicente de Rocafuerte, subsequent president of that country; the Columbian José Fernández Madrid, who had been the president of the first republic of that country; and the Peruvian Manuel Lorenzo Vidaurre. The Venezuelan general José Antonio Páez wrote in his memoirs: "in the $23^{\text {rd }}$ year the Minister of War, mister Pedraza, had authorized don Pedro Rojas for the operations and to communicate with the inhabitants of Cuba with the aim of fomenting the revolution that on that island is known by the name of Soles de Bolivar ${ }^{15}$."

The political agenda in the inner workings of the York Grand Lodge was evident at the fall of the Spanish constitutional regime in 1823. A document meant to determine whether they were willing to "declare and uplift the Constitution on this island in the probable case of the downfall of the Peninsula to the despotic system protected by the French government" circulated to its affiliates ${ }^{16}$.

\footnotetext{
${ }^{13}$ Miranda y Álvarez, Historia documentada, 43-44.

${ }^{14}$ Joel Robert Poinsett, Notas sobre México (México D.F.: Editorial Jus, 1950).

${ }^{15}$ José Antonio Páez, Autobiografía (Madrid: Biblioteca Ayacucho, s.f.), 455-456.

${ }^{16}$ Páez, Autobiografía, 25.
} 
Moreover the governor, Dionicio Vives, had to face the mutiny of the York and Scottish lodges that refused to obey royal orders. In fact, in the small town Vereda Nueva in Havana, one lodge was discovered and raided by the authorities, and its meeting was disbanded "to the strikes of machetes."

In the same year of 1824, the tracings of the first Cuban lodge, The Temple of the Theological Virtues, vanished definitively until now.

\section{Conclusions}

1. Freemasonry, like all human institutions, comprises not simply postulates and dogmas, but above all the characteristics and the ideals of its members. They are the ones who interpret, and place in relative form, the organization's general and abstract principles.

2. It is not possible to understand the history of Freemasonry without first specifying the political, economic, and social circumstances of the period. Part of the social threads that explain behaviors and ideas are found in the same social milieu in which the men who comprise the institution are immersed.

3. Freemasonry in America is a vigorous force that is tied to the formation of social thought - philosophic and juridical - and to the spiritual thought that not only emanates from universal postulates, but even more from the reality that it is a part of.

4. The hold of Freemasonry in the broader ambit of Caribbean historical-cultural context follows a course foreign to monarchies and absolutisms. It is a strong force that has as an objective the formation of citizens with rights and duties that exercise the principles of full liberty, and the pursuit of a spirituality born of a human and physical nature that, as the Cuban philosopher Félix Varela used to say, "embraces all men from any part of the world" that wish to conquer the spirit, polish it, and elevate it to new horizons for all of humanity.

5. The Caribbean, described by Humboldt as the American Mediterranean, was a veritable siphon of races, customs, ideas, and above all of utopias and projects for new societies. The contribution of Freemasonry to this debate is transcendent. Beyond its practical objective, it was a diffuser of ideas that, at their own time, were re-elaborated and readapted from the realities of the nations that engendered their initial propositions in the first place. Slavery and the different systems of production, and similarly just like the difference in development, generate systems of ideas that are not tied to the heavy ballasts of traditional societies.

6. The history of the first Masonic lodge established in Cuba, the Temple of the Theological Virtues - which soon turned into the first Cuban lodge-is not only inextricably bound to important readjustments in the ideas of Freemasonry emanating 
from America, but also to its main role as the promoter of the first Cuban separatist project.

7. The first constitutional project created in Cuba (1811), of the first Mason Joaquin de Infante, precedes the first Spanish constitution of Cádiz (1812) and exceeds it in the number of liberties and in the creation of a lay republican state.

8. Freemasonry at the start of the nineteenth century, more than being just a single entity, is a plurality of Masonic bodies and tendencies, of rites and grades, of ideas and structures. The richness of the time period is essential to understanding not only the diversity of Freemasonry, but the diversity of its ethical, social, and spiritual propositions. The ending of the story does not fully explain the richness of its origins.

\section{Bibliography}

Collaveri, François. Napoleón franc-maçon? Paris : Taillandier Bibliothèque Napoléonienne, 2003.

Diario de la Habana 1812.

Franco, José Luciano. La Conspiración de Aponte. La Habana, 1963.

Infante, Joaquín. Homenaje a este ilustre bayamés autor del primer proyecto de constitución para la isla de Cuba. La Habana: Imprenta El Siglo XX, 1930.

Miranda y Álvarez, Aurelio. Historia documentada de la masonería en Cuba. La Habana, 1933.

Páez, José Antonio. Autobiografía. Madrid: Biblioteca Ayacucho, s.f.

Poinsett, Joel Robert. Notas sobre México. México D.F.: Editorial Jus, 1950.

Ponte Domínguez, Francisco. La masonería en la independencia. La Habana: Editorial Modas Magazins, 1954.

Revista La Gran Logia 1904.

Saunier, Eric. Encyclopédie de la franc-maçonnerie. France : La Pochothèque, 2000.

Torres Cuevas, Eduardo. Historia de la masonería cubana. Seis ensayos. La Habana: Editorial Imagen Contemporánea, 2004. 